\title{
EARLY SIGHTING OF A RARE BUTTERFLY, MORMON METALMARK, IN GRASSLANDS NATIONAL PARK, SK
}

ALLISON HENDERSON, PATRICK FARGEY and SHELLY PRUSS, Parks Canada, Box 150, Val Marie, SK, SON 2 TO and FELIX SPERLING, CW 405, Biological Sciences Bldg, University of Alberta, Edmonton, AB, T6G $2 E 9$

The Mormon Metalmark, Apodemia mormo (C. \& R. Felder), is a mediumsized butterfly of arid regions that is named for the white metallic markings on its wings (Figure 1, see inside back cover, top). ${ }^{4}$ It belongs to the tropical family Riodinidae and is this family's only Canadian representative. ${ }^{3}$ In Canada, there are two populations of Mormon Metalmark: the Southern Mountain Population in the Similkameen River Valley of British Columbia and the Prairie Population in and around Grasslands National Park (GNP) of south-western Saskatchewan. ${ }^{4}$ The Saskatchewan population was designated by the Committee on the Status of Endangered Wildlife in Canada (COSEWIC) as Threatened in 2002. ${ }^{1}$

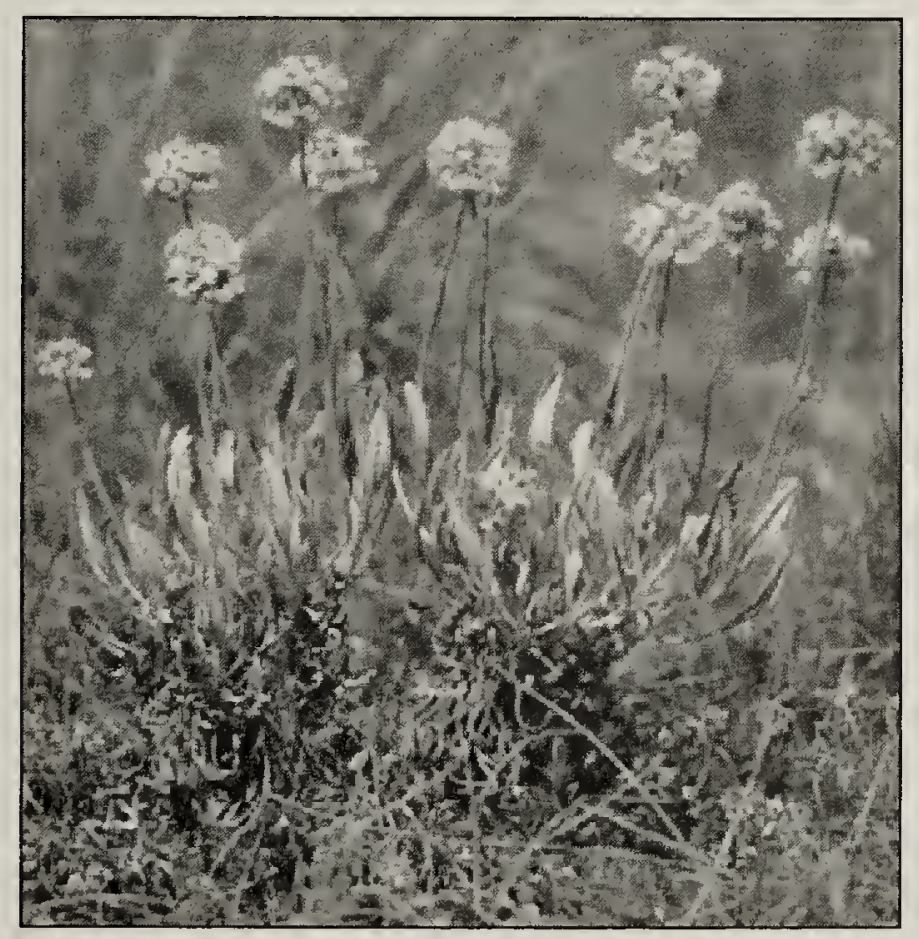

Figure 2. Flowering Branched Umbrella Plant (Eriogonum pauciflorum) in GNP A. Henderson
For this reason, the Mormon Metalmark has become a focal species for Species at Risk monitoring in Grasslands National Park.

The Mormon Metalmark is thus far known to occur on hillsides with barren clay or heavy clay soil where its host plant, the Branched Umbrella Plant, Eriogonum pauciflorum, (Figure 2) occurs. ${ }^{4}$ Adult metalmarks require mature, robust Branched Umbrella Plants for oviposition, and flowering Branched Umbrella Plant and Rubber Rabbitbrush, Ericameria nauseosa, (Figure 3) for foraging. ${ }^{4}$ Upon emergence, adults fly, forage and mate for 10 days; the adult flight period typically lasts until late August or early September. ${ }^{4}$ Mormon Metalmark larvae

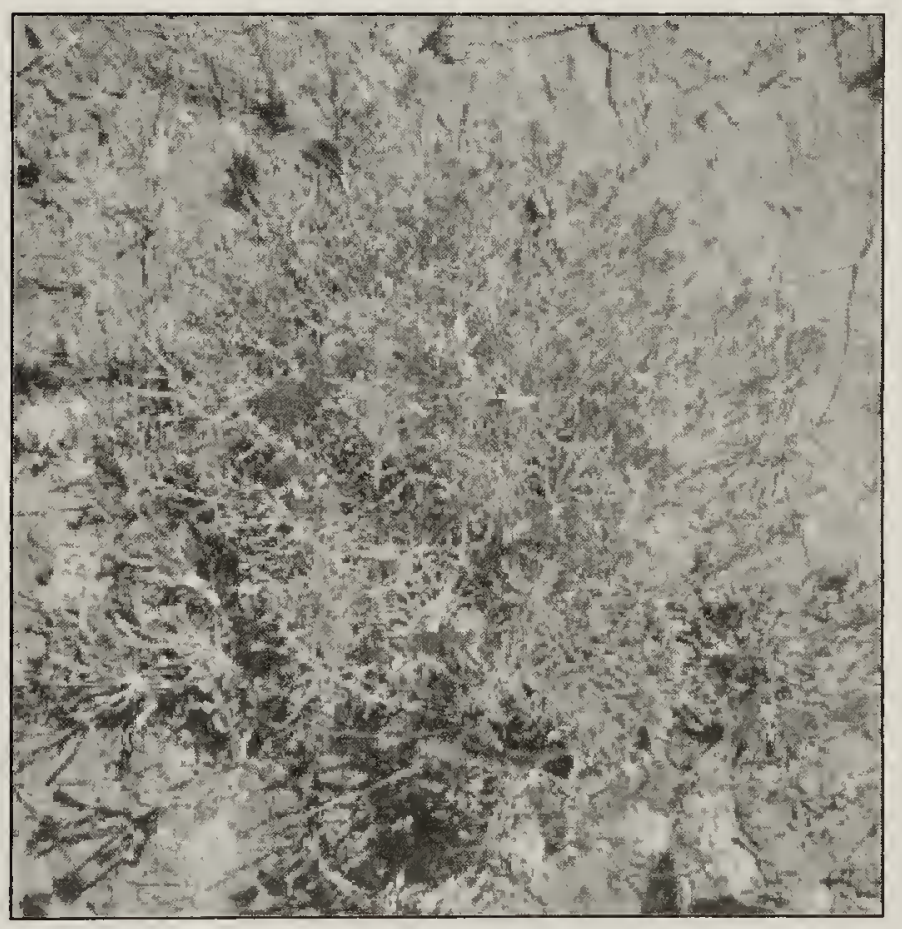

Figure 3. Flowering Rubber Rabbitbrush (Ericameria nauseosa) in GNP

A. Henderson 
require the branched umbrella plant's leaves for feeding and probably need its woody stems and underlying leaf litter for overwintering.

The Mormon Metalmark ranges from northern Mexico through the western United States to southern British Columbia and Saskatchewan ${ }^{1}$ and adult emergence times vary throughout this range. Adult Mormon Metalmarks need nectar, and the metalmark flight period coincides with the flowering period of E. pauciflorum. ${ }^{4}$ In British Columbia, adult metalmarks are typically in flight from mid-August to late September with peak activity during August. $^{2}$

In the past, surveys for Mormon Metalmark in Saskatchewan have been conducted in mid- to late August. From August 13 to September 11, 2002, Ron Hooper of the Saskatchewan Royal Museum surveyed for Mormon Metalmark in and around GNP and identified 6 locations where adult Mormon Metalmark were observed in flight. In August of 2006, GNP staff surveyed the West Block of GNP and identified two new Mormon Metalmark locations. Recent observations suggest that metalmark surveys should begin earlier. On July 23, 2007, amidst ambient temperatures of $40.3^{\circ} \mathrm{C}$, we visited the badlands of Grasslands National Park in search of Mormon Metalmark. Temperatures in GNP on that day reached a record-breaking high for the region. Much to our delight, we found an estimated 10 to 20 adult Mormon Metalmarks feeding and mating in a large, dense, flowering patch of their host plant, Eriogonum pauciflorum. This is the earliest recorded sighting for the Mormon Metalmark in Saskatchewan. Our observations suggest that metalmark surveys in southwestern Saskatchewan should coincide with $E$. pauciflorum flowering, which may begin in early to mid-July (A. Henderson, personal observation).

Saskatchewan's grasslands are home to an incredible diversity of insects. If you would like more information about the arthropods of Grasslands National Park, please contact Allison Henderson, Grasslands National Park Species at Risk Monitoring Technician.

1. COSEWIC. 2002. COSEWIC assessment and update status report on the Mormon Metalmark Apodemia mormo in Canada. Committee on the Status of Endangered Wildlife in Canada. Ottawa.

2. GUPPY, C.S. and J.H. SHEPARD. 2001. Butterflies of British Columbia. UBC Press, Vancouver

3. LAYBERRY, R.A., P.W. HALL, and J.D. LAFONTAINE. 1998. The Butterflies of Canada. University of Toronto Press, Toronto, Ontario

4. PRUSS, S.D., A. HENDERSON, P. FARGEY, and J. TUCKWELL. 2007. Recovery Strategy for the Mormon Metalmark (Apodemia mormo) Prairie Population, in Canada [Proposed]. Species at Risk Act Recovery Strategy Series. Parks Canada Agency. Ottawa.

"Nothing is more humbling than to look with a strong magnifying glass at an insect so tiny that the naked eye sees only the barest speck and to discover that nevertheless it is sculpted and articulated and striped with the same care and imagination as a zebra. Apparently it does not occur to nature whether or not a creature is within our range of vision, and the suspicion arises that even the zebra was not designed for our benefit." Rudolf Arnheim, psychologist and author (1904-2007) 